\title{
Project Based Learning in Teaching Mandarin as Foreign Language: Theory to Practice
}

\author{
Eng Li Yin, Khor Teik Huat
}

To Link this Article: http://dx.doi.org/10.6007/IJARBSS/v11-i4/9699

DOI:10.6007/IJARBSS/v11-i4/9699

Received: 05 February 2021, Revised: 10 March 2021, Accepted: 28 March 2021

Published Online: 17 April 2021

In-Text Citation: (Yin \& Huat, 2021)

To Cite this Article: Yin, E. L., \& Huat, K. T. (2021). Project Based Learning in Teaching Mandarin as Foreign Language: Theory to Practice. International Journal of Academic Research in Business and Social Sciences, $11(4), 542-551$.

\section{Copyright: (c) 2021 The Author(s)}

Published by Human Resource Management Academic Research Society (www.hrmars.com)

This article is published under the Creative Commons Attribution (CC BY 4.0) license. Anyone may reproduce, distribute, translate and create derivative works of this article (for both commercial and non-commercial purposes), subject to full attribution to the original publication and authors. The full terms of this license may be seen

at: http://creativecommons.org/licences/by/4.0/legalcode

$$
\text { Vol. 11, No. 4, 2021, Pg. } 542 \text { - } 551
$$

Full Terms \& Conditions of access and use can be found at http://hrmars.com/index.php/pages/detail/publication-ethics 


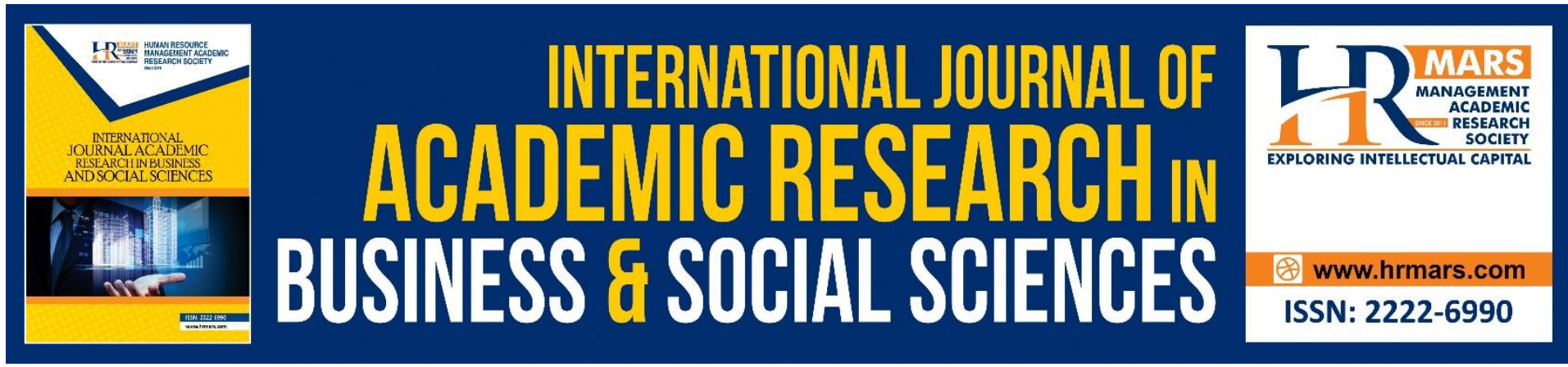

\title{
Project Based Learning in Teaching Mandarin as Foreign Language: Theory to Practice
}

\author{
Eng Li Yin, Khor Teik Huat \\ Modern Language Department, Faculty of Language and Communication, Sultan Idris \\ Education University, Malaysia. \\ Email: joaan1989@gmail.com
}

\begin{abstract}
Project-based learning ( $\mathrm{PjBL}$ ) emerges as a model that meets the needs of both teachers and students in teaching and learning a foreign language effectively. PjBL in the field of Mandarin as Foreign Language (MFL) are still new. This article with the aims to discuss the definition and the benefits of PjBL. It is also deals with the steps for implementing the PjBL project in class. Finally, the suggestion of implementing PjBL activities in Mandarin class for beginners have been detailed.
\end{abstract}

Keywords: Project-Based Learning, Project Steps, Mandarin As Foreign Language, Mandarin Class Project Activities, Beginners

\section{Introduction}

Project Based Learning (PjBL) was introduced in Malaysia since 2006 (BTP, 2006). It is seen as one of the teaching and learning methods that can improve students' knowledge or skills with experienced and solving problem related to the real world. Due to these criteria, PjBL has been recognized as an effective $21^{\text {st }}$ century education (Pham, 2018). However, PjBL studies are still new and growing in Malaysia (Wan et al, 2020) especially in the field of Mandarin as Foreign Language (MFL). There is only one study of PjBL in the field of MFL has been found in Malaysia, which is about MFL in vocational college by Eng (2020). There is also a limited study about PjBL in MFL and still in the review stage (Xing, 2020; Li, 2014; Zhou, 2013).

$\mathrm{PjBL}$ is not a new teaching method in pedagogical studies. PjBL was first introduced by David Snedden, who teach Science subject in vocational agriculture classes in America (Beckett, 2006). It came from the idea of John Dewey, who trusted that someone learning by doing is better than only listen to the information given by the teacher (Collier, 2017). Later, PjBL was developed and popularized by William Heard Kilpatrik, John Dewey's student, in his article namely "The Project Method" in 1918, which stated that there is a need for students to do purposeful activities (Beckett, 1999). Students need to apply the learned knowledge based on existing knowledge and new knowledge in related situations.

PjBL was not applied in Foreign Language education in the beginning, but is widely applied in the field of Science education (Kavlu, 2015). PjBL was only introduced in the field of Foreign 
Language education in the 1980s due to the educators' interest in the principles of studentcentered learning, autonomy and cooperative contained in PjBL (Hedge, 1993). After that, project-based learning has become a popular activity in teaching language in various levels and contexts (Beckett, 1999; Yahya Othman \& Suzanawaty Osman, 2014; Esmail Zare-Behtash \& Tayebe Sarlak, 2017; Noor Idayu Abu Bakar et al., 2019).

Thus, this paper would like to discuss some fundamental aspects of PjBL by focusing on the explanation of PjBL, the benefits of $\mathrm{PjBL}$ in Mandarin class, steps for implementing a PjBL project and the suggestion of implementing PjBL activities in Mandarin class.

\section{Definitions of Project Based Learning}

There are many definitions for project based learning. Buck Institute for Education (BIE, 2019), stated that PjBL is a teaching method which guide students to learn actively associated with the real world and produce a meaningful project. Students need to work on the project in a week or for a semester involving them resolve issues related to the real world or answer a complicated question. At the end of learning, the skills such as critical thinking, cooperation, creativity and communication can be developed in depth indirectly.

Beckett (2006) said that PjBL is a student-centered teaching method which the students get the knowledge and skills through solving some task individually or in a group with the help of the teacher and friends by using the information that had learned during solving problem that related to the real world. The students have to present their final product orally or in a written report at the end of the learning process (Beckett, 2002).

Same with Beckett (2006); Zhou (2013) also mention that PjBL is a student-centered teaching method. The students have to implement challenging authentic task, collect and analysis information, produced quality authentic product and present the product with the teacher's guide. PjBL provides student the environment to use the target language.

$\mathrm{PjBL}$ is carried out based on the teaching objective and teaching syllabus (Niu, 2019). It begins with the questions. Under the teacher's guide, students' study in a small group to solve the real problem. Their language knowledge and communication ability will be improved.

While according to Xing (2020), PjBL is a teaching method which the project as a connection between students, teachers and the teaching contents. These combination leads to student learning, guidance from teachers and evaluation for the project outcomes. It fosters student autonomy and other learning skills.

$\mathrm{PjBL}$ in the foreign language class, Moritoshi (2017) stated it is an approach which need students work in a small group to produce a product by using target language. During the task, it provides the needs to communicate continuously which can fulfil by using authentic target language, meaningful, contextual and self-centered. It can be seen that PjBL brings to the knowledge construction derived from previous knowledge, experience, and interaction with the social environment (Sadrina et al., 2018).

In the other way, Ciptro \& Arianal (2018) pointed out that PjBL is a teaching approach because it can be used by teachers to deliver syllabus based on predetermined learning outcomes. At 
the same time, $\mathrm{PjBL}$ is said to be a learning approach because it is based on theories of learning such as constructivism and also learning through experience. So, PjBL is a studentcentered learning approach, in which students have to investigate, involving in decisionmaking process based on data analysis, collaboration, product-oriented and involving in document preparation.

Based on the discussion above, PjBL can be concluded as teaching and learning approach. This is because teacher delivers the content of learning syllabus and guide students to implement the project so that students can more understand what they have learned. The project can be done individually or in group and can be a short term or long term. Students have to find the information, work collaborative, creative and apply what they had learned to produce a final product based on the real situation question. Students have chances to communicate using the target language during the PjBL activities and it brings to improve their language skills such as speaking skills and social skills.

Thomas (2000) had proposed five criteria of PjBL as below:

1. $P B L$ projects are central, not peripheral to the curriculum.

2. PBL projects are focused on questions or problems that "drive" students to encounter (and struggle with) the central concepts and principles of a discipline.

3. Projects involve students in a constructive investigation.

4. Projects are student-driven to some significant degree.

5. Projects are realistic, not school-like.

With these distinctive features, PjBL had drawn attention of the researcher and educator. Previous studies had proved that PjBL have many benefits. It is a need to discuss about the benefits of PjBL in the next section.

\section{Benefits of Project Based Learning in Teaching Mandarin as Foreign Language}

Mandarin has been taught as a foreign language in Malaysia for a long time. However, there has been little application of the Project Based Learning in teaching. There are a few benefits applying PjBL in MFL classes in the previous studies.

First, PjBL helps to improve language skills such as speaking skills, listening skills, reading skills and writing skills. Lui (2013) stated that with the project activities in the class, students can improve their speaking skills in the aspect of pronunciation. Through the project activities, students can apply what they had learned in the real situation and understand well the learning material (Amalia et al., 2019). Zhou (2014) proves that after joining the project activities in class, the students get good performance in accuracy, fluency and complexity which is the element of the communication. Besides that, Niu (2019) also mentions that, student's communication skills not only improve but also more willing to speak in Mandarin when doing PjBL activities.

Second, PjBL had increase student's learning motivation. Lui (2013) study showing that students are more concentrated and motivated during learning Mandarin with the implementation of project activities. Students will notice their own weakness and will have a high desire to improve it when implementing the project activities (Zhao \& Beckett, 2014). At 
the same time, student's interest in learning Mandarin also increase (Xing, 2020; Niu, 2019; Li, 2014).

Third, with the PjBL lesson, students are more independent in learning (Xing, 2020) and more creative and collaboration during producing the final product (Zhou, 2014). This is because students need to implement the project by group and to find the solution when producing the final product.

PjBL seem like suitable applying in foreign language classes include MFL classes. Beside the benefits of $\mathrm{PjBL}$, it is important to know how to implement $\mathrm{PjBL}$ in foreign language classes.

\section{Steps for Implementing a Project Based Learning Project}

PjBL is a learning model that surrounded the project (Thomas, 2000). Niu (2019) stated that, project in MFL is a learning activity that implement between teacher and students based on student's interest, needs for real communication, teaching curriculum and the student's actual level. It needs to be student-centered, based on real life situations and provides students the opportunity to communicate in the target language.

Furthermore, most of the students who study Mandarin as Foreign Language are beginners. Therefore, the steps for implementing PjBL play an important role to ensure that students understand the basic learning process through project. At the same time, the steps need to help both teacher and students during organise the PjBL activities.

There are a few models to implement PjBL in the language classes. Li (2014) argues that a project in Mandarin language classes covers four steps, which is determine the project, planning, implementing project and evaluate the final product of the project.

Niu (2019) in her thesis introduces a model which illustrates the process of project work in six steps. Step 1 determines the project theme. Step 2 determine project planning: this step include planning teaching objective, teaching contents, teaching time and project activities that need to implement. Step 3 exploration: in this step, students need work in small group and learn new knowledge or skills to obtain project solution information. Step 4 producing project final product. Step 5 sharing experience of projects production: students present the project final outcome and sharing the experience about the project production process. Step 6 evaluation: evaluation is done based on self-assessment, group member assessment and project performance evaluation.

Based to the above models, ten steps Stoller (1997) model seem like can clearly explain the implementating PjBL steps in class which involve both teacher and students. Alan and Stoller (2005) had apply this model in their research namely "Maximizing the Benefits of Project Work". The ten steps can be summarized as below:

Step 1: Students and teacher agree on a theme for the project

Students are allowed to give an opinion and choose the project theme. The project ranges from structured, semi-structured to unstructured to how the teacher defines the project. Although teacher can decide the project type, but the student is encouraged to decide the project theme. 


\section{Step 2: Students and teacher determine the final outcome of the project}

Students and teacher determine the final outcome of the project, such as written report, presenting orally, pamphlet and video. Furthermore, students and teacher also discuss the suitable audience for the project. It can be classmate, student from other class, parents and etc.

Step 3: Students and teacher structure the project.

After the theme and final outcome of the project are defined, students and teacher figure out the project contents. Some questions need to be considered before starting a project: "What information is required to complete the project?", "How to collect the needed information?", "How to categorize and analyse the information?" and "What is the duration for the project implementation?".

Step 4: Teacher prepares students for the demands of information gathering Teacher have to provide the language needed, which suitable with the student's level so that the students can gather the information. As an example, students will be conducting interviews with people to gather information, therefore teachers should provide guidance on the format of questions and how the conversation.

\section{Step 5: Students gather information}

After students practice language, skills and strategies, they need to gather information. Teachers need to provide relevant content resources when necessary.

Step 6: Teacher prepares students to compile and analyze data

In this step, students will face challenges in the category and analysis of information. Therefore, teachers need to provide a session so that students can practice language skills in categories, evaluate, analyse and interpret information.

\section{Step 7: Students compile and analyse information}

The former stage is a simulated practice, and this stage is the practical operation. The students will organize and analyse data with the assistance of a variety of organizational techniques.

Step 8: Teacher prepares students for the language demands of the final activity After the students successfully analyse data before presenting the final project, the teacher needs to prepare some activities for practicing skills of the presentation.

\section{Step 9: Students present the final product}

At this stage, the students will present their final project on which they have done with a lot of effort.

Step 10: Students evaluate the project

Although viewing the final project presentation is the final step, evaluating projects is necessary for reflecting what the students have learned. Students reflect on what they learned through the project. Students also stated the improvement suggestions for their next project. Teachers provide feedback on language learning and student performance.

It is clear that this Stoller model more clearly and easily implemented by both students and teacher. Each step plays a crucial role in completing a successful project. Stoller (1997) stated 
that teacher can exclude some unnecessary steps based on project suitability. Therefore, with the modification of this Stoller model (1997) and the steps proposed by researchers in the field of MFL can help students understand the learning contents, practice language skills and increase the motivation of learning Mandarin.

\section{Suggestion of Implementing Project Based Learning Activities in Mandarin Language Class}

Learning Mandarin as Foreign Language which introduce in Malaysia secondary education is only involve the beginning level. The main purpose of introducing Mandarin as Foreign Language is to cultivate students to communicate in the target language in daily life. As stated in vocational college mandarin curriculum, at the end of the study, student can communicate in mandarin using simple sentence and pronounce correctly in the related situation (KSKV, KPM, 2018). Because the students are beginners in learning Mandarin, Li (2014) argue that a short-term project is more suitable and easier to handle by the students and more focus in the learning topic. It is also can more focus to cultivate the student's language skills, such as speaking skills (Li, 2014). Some speaking project as suggested by Van Lam (2011) like speeches, presentation, debate, drama, role play and so on can be launch in class. The project can be in video record. Therefore, the implementing PjBL activities in Mandarin classes must be easier to handle and understand by both teacher and students. Below is the suggestion for implementing PjBL activities in mandarin classes which focus on cultivate students' speaking skills:

Step 1: Students and teacher agree on a theme for the project

Teacher introduce the project theme which based on the learning topic. The project begins with the question which related to the theme.

Step 2: Students and teacher determine the final outcome of the project

Teacher and students decide the final outcome of the project. The final outcome product can be a menu, photobook, video or map and the presentation method can be in role play.

Step 3: Students and teacher structure the project.

Teacher and students discuss about the project's contents based on each theme and the duration for producing product.

\section{Step 4: Teacher prepares students the needed language}

Teacher provide the needed language such as vocabulary, grammar (sentences) and the pronunciation based on the learning topic. It is easier for students to implement the project with the vocabulary and grammar based on the related topic (Zhao \& Beckket, 2014). Students have the opportunity to apply the learned language in the real context (Amalia, et al., 2019) and enhances the understanding of the learning concept (Ong, et al., 2017).

\section{Step 5: Students gather information}

Students discuss and divide the work with group members. They find the information through internet. In this step, students will practice with their group members using target language.

Step 6: Students doing preparation for the presentation

Students who are ready doing rehearsal in class. At the same time, teachers correct their script, pronunciation and grammar. 


\section{Step 7: Students present the final product}

Students present their final product in class.

Step 8: Students and teacher evaluate the final outcome

Teacher evaluate student's performance using the project rubric. While students doing reflection about the project by using self and group members assessment form.

\section{Conclusion}

This article presented various definitions of PjBL and its benefits in Mandarin language learning. Besides that, the steps for implementing a PjBL project also have discussed. The suggestion of implementing PjBL project by adaptation of Stoller (1997) model and the previous studies also have been detailed to accommodate with the MFL learning situation in vocational college, Malaysia. With this explanation, hope to give an idea to the Mandarin teachers in the implementation of the PjBL in classes especially for beginners. This teaching approach can be applied in Mandarin classes so that students know how to use the learned materials in real situations, improve language skills and improve social skills.

\section{Corresponding Author}

Khor Teik Huat

Modern Language Department, Faculty of Language and Communication, Sultan Idris Education University, Malaysia.

Email: khor_teik_huat@fbk.upsi.edu.my

\section{References}

Alan, B., \& Stoller, F. L. (2005). Maximizing the Benefits of Project work in Foreign Language Classrooms. English Teaching Forum, 43(4), 10-21.

Amalia, I. P., Abidin, S. F. F., \& Safitri, S. R. (2019). Project-based Learning in Chinese Classroom: A Way to Stimulate Students. International Seminar on Language, Education, and Culture, KnE Social Sciences, 77-84.

Beckett, G. H. (1999). Project-based instruction in a Canadian secondary school's ESL classes: Goals and evaluations (Doctor of Philosophy Thesis). University of British Columbia British Columbia,Canada.Beckett, 2002.

Beckett, G. H. (2006). Project-based second and foreign language education: theory, research, and practice. In G. H. Beckett \& P. C. Miller (Eds.), Project-based second and foreign language education: Past, present, and future. Connecticut, USA: Information Age Publishing Inc.

Buck Institute for Education. (2019). Project Work Report. Retrieved from https://my.pblworks.org.

Bahagian Teknologi Pendidikan Kementerian Pendidikan Malaysia. (2006). Project-Based Learning Hanbook. Communication and Training Sector, Kuala Lumpur.

Ciptro, H., \& Arianal, M. R. (2018). Project Based Learning: A Review of Literature On Its Outcomes And Implementation Issues. LET: Linguistics, Literature and English Teaching Journal, 8(2), 110-129.

Collier, L. D. (2017). Using a Project-Based Language Learning Approach in the High School Spanish Classroom: Perceived Challenges and Benefits (Master Thesis). Brigham Young University. 
Eng, L. Y. (2020). A Concept Paper: The Effectiveness of Project Based Learning on Speaking Skill among Non-Native Mandarin Learners in Vocational College Malaysia. International Journal of Academic Research in Business and Social Sciences, 10(7), 638-646.

Zare-Behtash, E., \& Sarlak, T. (2017). The Effect of Project Based Learning (PBL) on the Components of Speaking Ability of Iranian EFL Beginner Learners. Journal of Applied Linguistics and Language Research, 4, 119-130.

Hedge, T. (1993). Key Concepts in EFL: Project Work. ELT Journal, 47(3), 275-277.

Kavlu, A. (2016). Enhancement of English as a Foreign Language (EFL) University Students' Reading Skills through Project-Based Learning Implementation (Doctoral Dissertation). International Black Sea University.

Kementerian Pendidikan Malaysia. (2018). Kurikulum Standard Kolej Vokasional Bahasa Mandarin Diploma Kolej Vokasional Malaysia.

Li, X. (2014). Dui Wai Han Yu Jiao Xue Zhong de Xiang Mu Jiao Xue Fa Tan Suo (Master Thesis). Universiti Perguruan Nanjing.

Lui, X. X. (2013). A Course Design of Intermediate Spoken Chinese with Project Teaching Method (Master Thesis). Jilin University China.

Moritoshi, T. P. (2017). The Perceived English Language Learning Outcomes Associated with Project-Based Language Learning: A Case Study at a Japanese Junior College (Doctor of Philosophy Thesis), Aston University.

Niu, H. Y. (2019). The Teacher Design of Elementary Chinese Comprehensive Course For Thailand Based on Project Based Learning - Taking Animal As An Example (Master Thesis). Anyang Normal University.

Ong, E. T., Norazura, A., Zaharah, M. J., Sabri, M. H., \& Abdul, M. H. M. N. (2017). Stem Education Through Project-Based Inquiry Learning: An Exploratory Study on Its Impact Among Year 1 Primary Students. Jurnal Pendidikan Sains \& Matematik Malaysia, 7(2), 44-51.

Pham, D. T. (2018). Project Based Learning: from Theory to EFL Classroom Practice. Proceedings of the 6th International Open TESOL Conference, 327-339.

Stoller, F. L. (1997). Project Work: A Means to Promote Language and Content. English Teaching Forum, 35 (4), 2.

Thomas, W. J. (2000). A Review of Research on Project-Based Learning. Retrieved from http://www.bie.org/research/study/review_of_project_based_learning_2000

Van Lam, N. (2011). Project-based learning in teaching English as a foreign language. VNU Journal of Science, Foreign Languages, 140-146.

Wan, H., Wan, R., Che, G. C. K., \& Arman, S. A. (2020). Keberkesanan Pembelajaran Berasaskan Projek Terhadap Motivasi Intrinsik dalam Subjek Projek Tahun Akhir 1 (Pta1) di Kolej Vokasional Slim River. International Journal of Education, Psychology and Counselling (IJEPC), 5(34), 197-211.

Xing, S. (2020). A Case Study og Project Teaching Method Applied in Teaching Chinese Idioms to Foreigners (Master Thesis). Hebei University.

Zhao, J., \& Becket, G. H. (2014). Project based Chinese as a foreign Language Instruction - A teacher Research Approach. Journal of the Chinese Language Teachers Association, 49:2, 45-74.

Zhou, Y. (2013). Xiang Mu Jiao Xue Fa Gei Dui Wai Han Yu Jiao Xue De Qi Shi. Modern Chinese, 84-87. 
INTERNATIONAL JOURNAL OF ACADEMIC RESEARCH IN BUSINESS AND SOCIAL SCIENCES Vol. 11, No. 4, 2021, E-ISSN: 2222-6990 @ 2021 HRMARS

Zhou, Y. M. (2014). Kajian Aplikasi Pembelajaran Berasaskan Projek dalam Kelas Bahasa Mandarin sebagai Bahasa Asing (Tesis Sarjana). Universiti Perguruan Nanjing. 